\title{
The Comparison and Analysis of China Cross-border E-commerce Business Model*
}

\author{
Xingzhi Liu \\ School of Business Administration \\ Shandong University of Finance and Economics \\ Jinan,China \\ q_100@163.com
}

\author{
Rongkun Liu \\ Business School \\ Shandong Normal University \\ Jinan,China \\ Lrk8284@126.com
}

\begin{abstract}
The cross-border E-commerce is becoming a new growth point of China economics. As predicts 2020, the China cross-border E-commerce will reach 12 trillion Yuan. So the economic area should give it extensive attention and deep research. This paper analyzes the development stages and situations of China cross-border E-commerce and according the value chain analysis method researches the business models of China cross-border E-commerce. By the specific cases, the paper analyzes the cross-border E-commerce enterprises how to participate in business operations and how to benefit. The results of the paper can provide some theoretical basis for industry and enterprise applications and give some suggestions and guidance for the traditional import and export trading businesses to transform to be cross-border E-commerce platforms.
\end{abstract}

Keywords-Cross-border E-commerce; E-commerce business model; profit model

\section{INTRODUCTION}

\section{A. The Conception of Cross-border E-commerce}

The cross-border E-commerce as a new kind of trade way and a kind of more advanced e-commerce form is that both trading sides in different countries or regions trade through the Internet and other information trading platform. ${ }^{[1]}$ The crossborder E-commerce has become the development trend of China foreign trade and its position and function in international trade is growing. ${ }^{[2]}$

\section{B. The development stages of China Cross-border E-} commerce

The development of China cross-border e-commerce has experienced three stages ${ }^{[3]}$ (Fig.1):

Fig. 1. Development stages of China Cross Border E-Commerce

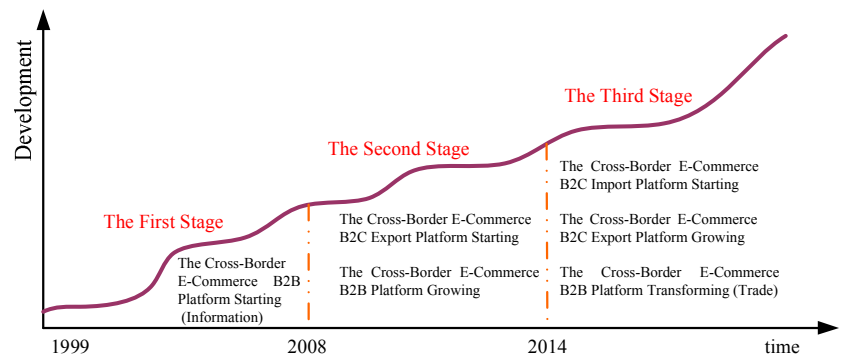

Source: AliResearch. The China cross-border E-commerce development report 2016 [R].G20 series study,2016.9
The first stages of germination (1997-2007): China crossborder E-commerce started in the end of $20^{\text {th }}$ century represented by export B2B platform of Aalibaba.com and Made-in-China.com, china.chemnet.com, etc. These platforms provide basic services such as commodity information display and trade matching and so on for small and medium-sized enterprises' export. Aalibaba.com is currently the world's largest cross-border B2B platform.

The second stages of development (2008-2013): With the improvement of the global Internet penetration and the raising service level of cross-border payment, logistics and so on, around 2008, facing the overseas consumers the Chinese crossborder E-commerce retail business $(\mathrm{B} 2 \mathrm{C} / \mathrm{C} 2 \mathrm{C})$ flourished. Lightinthebox (2007) and AliExpress (2009) conforming to the trend grow to be cross-border E-commerce B2B websites. The development of cross-border E-commerce retail makes great changes of international trade body and trade way. A large number of small and medium-sized enterprises and websites started to directly involve in the international trade.

The third stages of outbreak (2014-present): in 2014 the regulation system innovations of China cross-border Ecommerce import promoted the rapid development of China cross-border E-commerce import and gave birth to a large number of cross-border E-commerce retail platforms including TMALL.HK, kaola.com, ymatou.com, xiaohongshu.com, etc. The whole industry ushered the explosive growth in 2015.

Since the end of 20th century China cross-border Ecommerce has began to change the marketing way of the traditional international trade. And with the rapid development of global Internet infrastructure the current cross-border Ecommerce has been revolutionarily and substantially influencing the international trade operation modes and trade chains. Small and medium-sized enterprises and individuals deeply involve all aspects of international trade. The enterprises can interact and trade directly with the global consumers.

\section{The development situations of China Cross-border E- commerce}

Influenced by international economics and the transformation of domestic economics, in 2015 the total volume of China import and export trade declined 1.7\% drop in export trade and $13.2 \%$ drop in import trade (Fig. 2$)^{[4]}$.

While global trade growth is slowing, China cross-border E-commerce is growing and the E-commerce proportion of import and export trade is continually improving. In 2015, China cross-border E-commerce transaction scale was 4.8 trillion yuan RMB and year-on-year growth was $28 \%$. 
Estimated in 2020 China cross- border E-commerce transaction scale will be 12 trillion yuan RMB and compound annual growth rate will be $20.1 \%$ (Fig.3).

Fig. 2. 2012-2018 The Total Volume of China Import Trade \&Export Trade

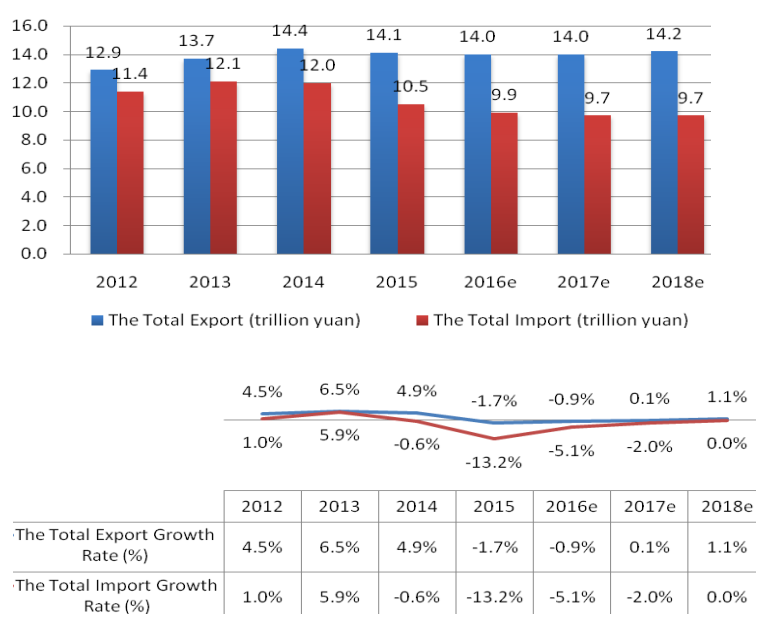

Source: the data before 2015 comes from the General Administration of

Fig. 3. The Total Import and Export trade Development of China CrossBorder E-Commerce

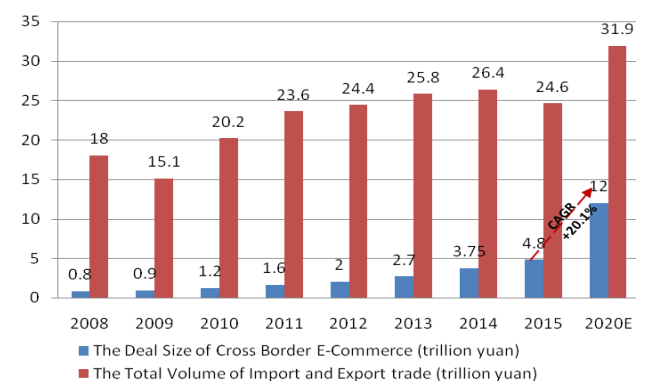

Source: The Ministry of Commerce、General Administration of Customs、

iRearch、Analysys.cn、AliResearch

The China cross-border E-commerce is export-oriented. In 2015, China export volume of cross-border E-commerce accounts for $83.1 \%$ of the total volume of cross-border Ecommerce trading. China cross-border E-commerce import account rate in the total volume of cross-border E-commerce is $16.9 \%$ and is predicted up to $25 \%$ in 2020 (Fig.4).

Fig. 4. 2012-2020 the Proportion rate of Export and Import trade in China cross-border E-commerceTotal Trade

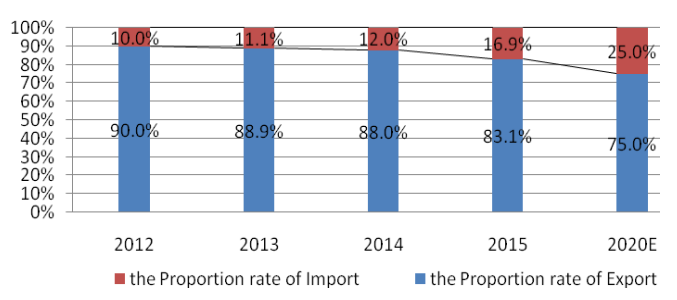

Source: The Ministry of Commerce、General Administration of Customs 、 iRearch、Analysys.cn、AliResearch

\section{The Business Models of ChINA CROSS-BORder E- COMMERCE}

\section{A. The business model introduction of China cross-border E- commerce}

There are several mainstream views in academic community about the concept of "business model":

First kind of view is that business model mentions how enterprises profit. American professor Michael Rappa considered that a business model is a method of doing business. All business models specify what a company does to create value, how it is situated among upstream and downstream partners in the value chain, and the type of arrangement it has with its customers to generate revenue. ${ }^{[6]}$ Peter Weill pointed out that business model is the description of the relationships between enterprises, consumers and suppliers. ${ }^{[7]}$ These views are all typical profit model viewpoint.

Second kind of view is multidimensional definition of business model. For example, European scholar Paul Timmers defined business model as : ${ }^{[8]}$

- An architecture for the product, service and information flows, including a description of the various business actors and their roles; and

- A description of the potential benefits for the various business actors; and

- A description of the sources of revenues.

In this paper, the cross-border E-commerce business model research is based on the last point of view. So this paper will not only research the profit pattern of E-commerce enterprises, but also study E-commerce enterprises how to participate in business operations, how to benefit and how to realize value sharing from the perspective of value chain.

\section{B. The business model types of China cross-border E- commerce}

According the value chain analysis method, this paper will divide the business models of China cross-border E-commerce into the self-run E-commerce model, the information platform model and the integrated service provider model(TABLE1).

TABLE I. THE CROSS-BORDER E-COMMERCE BUSINESS MODEL SUMMARY CHART

\begin{tabular}{|c|c|c|c|c|}
\hline \multirow{2}{*}{ benefit model } & \multirow{2}{*}{$\begin{array}{c}\text { value creation } \\
\text { process }\end{array}$} & \multirow{2}{*}{$\begin{array}{l}\text { value creation } \\
\text { mechanism }\end{array}$} & \multicolumn{2}{|c|}{ typical enterprises } \\
\hline & & & Export & Import \\
\hline $\begin{array}{l}\text { Self-run E- } \\
\text { commerce } \\
\text { model }\end{array}$ & $\begin{array}{l}\text { Products sale } \\
\text { links }\end{array}$ & $\begin{array}{l}\text { Costs decline, } \\
\text { Profitability } \\
\text { improved } \\
\text { Sales increase }\end{array}$ & $\begin{array}{c}\text { lightinthebox } \\
\text { DX } \\
\text { milanoo }\end{array}$ & $\begin{array}{c}\text { kaola } \\
\text { jumei } \\
\text { xiaohongshu }\end{array}$ \\
\hline $\begin{array}{c}\text { Information } \\
\text { platform } \\
\text { model }\end{array}$ & $\begin{array}{c}\text { Soliciting } \\
\text { platform users }\end{array}$ & $\begin{array}{l}\text { Membership fee, } \\
\text { Management fee }\end{array}$ & $\begin{array}{l}\text { GlobalSources } \\
\text { made-in-china }\end{array}$ & 1688 \\
\hline $\begin{array}{c}\text { Integrated } \\
\text { service } \\
\text { provider } \\
\text { model } \\
\end{array}$ & $\begin{array}{l}\text { Customer } \\
\text { make deals, } \\
\text { value-added } \\
\text { services }\end{array}$ & $\begin{array}{c}\text { Order } \\
\text { commission, } \\
\text { Services } \\
\text { consulting fees } \\
\end{array}$ & $\begin{array}{c}\text { Alibaba } \\
\text { aliexpress } \\
\text { onetouch.alibaba } \\
\text { dhgate }\end{array}$ & $\begin{array}{c}\text { Ymatou } \\
\text { Tmall.HK } \\
\text { JD } \\
\text { Wordwide } \\
\end{array}$ \\
\hline
\end{tabular}

- The self-run E-commerce model

The self-run E-commerce model often refers to that enterprises operate unified products' production or procurement, product display, online transaction and logistics distribution to final consumer. The enterprises of this model form their own supply chain and build their own foreign trade 
platform to sell products to overseas. The self-run Ecommerce model has some advantages including strong control on self-brand, product quality and complete trading process management system.

The two notable characteristics of self-run E-commerce model are the product type centralization and small goods package. The product type centralization refers to that this kind of E-commerce model selects one or several highly profitable products such as $3 \mathrm{C}$, wedding dress, etc. The small goods package refers that the customers are mainly the terminal consumers, so logistics only need specific international express to solve. The value chain of self-run Ecommerce model is the same as traditional enterprise including basic activities and supporting activities. Selling products to highly profitable market is the important way to increase profits of self-run E-commerce model.

The self-run cross-border E-commerce model can lower the barriers of traditional international trade and actually solve the pathway problem for enterprises from single domestic market to the international market. This kind of cross-border E-commerce model more suits to the certain scale producers and enterprises who have the abilities of building outside supply chain and the APP softwares or websites quickly known by overseas consumers who are willing to try. So the self-run cross-border E-commerce websites should have basic IT infrastructure and overseas informatization development abilities and resources.

\section{- The information platform model}

The information platform model aggregates both buyers and sellers information and provides them to suppliers or customers who trade directly. Its main profit model includes membership services and value-added services. The platform users need pay the membership fee every year for various services provided by the platform. The membership fee is the main source of the platform income. The value-added services provided by the platform after buyers and sellers freely being membership include competitive ranking, pay per click and booth promotion service. The competitive ranking is the most mature revenue model of information service platform valueadded services. ${ }^{[9]}$

Alibaba.com and GlobalSources.com are the typical B2B platforms of this cross-border E-commerce business model. Alibaba.com founded in 1999 is the famous brand of the world B2B electronic commerce and provides trading opportunities information and convenient online trading for millions of enterprise. GlobalSources.com founded in 1971 is the Asian earlier trading information providers and provides purchasing information for buyers. The cross-border E-commerce enterprisers of the information platform model are just the information display platforms for different countries or regions enterprises and the main income source of them is certain amount of membership fee.

The biggest difference between the information platform model and self-run model lies in the information flow. The information flow of self-run model is guided and searched by E-commerce enterprises themselves spending a lot of information search costs. Otherwise the information platform model is very good at evading the risk of information costs' increase so greatly reduce the cost of the buyers or the sellers to seek information.

But information platform model also has its limitations. Due to information explosion, the effective information selection costs' increase becomes a difficult problem. So how to achieve adequate information classification and rapid selection and interaction are difficult problems.

\section{- the integrated service provider model}

The integrated service provider model is a new trend of Ecommerce. Its core function is no longer just limited to the product sales and develops in various aspects such as logistics, payment, product quality control, etc. The integrated Ecommerce platform involves in every trading links and business processes including buyers' and sellers' data,
products, trading, logistics, evaluation, marketing and so on. ${ }^{[9]}$

Many of China E-commerce enterprises such as JD.com, Tmall.com and so on are actively exploring the integrated service E-commerce mode. For example, JD.com has established its own logistics distribution system. In China cross-border E-commerce, dhgate.com and aliexpress.com are the representative enterprises of the integrated service provide model. This business model is different from GlobalSources.com for not only providing a trading platform, but also can help domestic export enterprises in logistics, payment, customer management, etc. The integrated service provider model is information platform + other supporting service to make business processing more quickly and directly.

\section{THE TYPICAL CASES OF CHINA CROSS-BORDER E- COMMERCE BUSINESS MODELS}

\section{A. Lightinthebox.com-self-run E-commerce model}

Lightinthebox.com established in 2007 with 3 million dollars registered capital is currently the top of China foreign trade websites. At the beginning of the company founded, it got the capital injection from American Silicon Valley and Chinese famous venture capital firms. ${ }^{[10]}$ Lightinthebox.com who has a series of suppliers and has its own data warehouse and long term logistics partners integrates supply chain services and is the China's leading cross-border E-commerce online B2C platform. There are more than 60000 kinds of products from 14 categories in Lightinthebox.com including clothing, electronic products, toys, jewelry, household items, sporting goods and so on. The characteristics of its business model include:

Firstly, focusing on the product processes from China's factories directly to abroad consumers. Lightinthebox.com proceeds goods procurement by itself and foreign trade operation through its cross-border E-commerce platform to obtain most of the profits by eliminating the intermediate links. But it also bears the risks in the whole transaction links.

Secondly, strictly controlling the upstream suppliers. In order to ensure the suppliers' products complying with export quality standards, Lightinthebox.com made the quality standard of related products and established the quality control team to give quality guidance to the supplier's production line and improve production efficiency. Lightinthebox.com strengthens the control of suppliers' inventory strategy. Its basic inventory strategy is on-demand warehousing. It requires that the time of suppliers can put products in storage after receiving orders is 10 to 14 days for customized products and 48 hours for standard products. And since the fourth quarter of 2011, Lightinthebox.com has requested the suppliers to stock up goods in advance. It requires suppliers to prepare some goods in advance into Lightinthebox.com's own warehouse. Only after the customers placing orders reckoned in Lightinthebox.com trading system, Lightinthebox.com feeds back funds to suppliers. In addition, Lightinthebox.com returns the backlog of goods in warehouse to suppliers according the trading volume. These strategies make Lightinthebox.com's inventory costs fell sharply and transfers most of the risk to the upstream suppliers. 
Finally, many marketing mix. The advertising marketing of Lightinthebox.com includes search engine advertising, alliance website marketing and social marketing. According to statistics, Lightinthebox.com has invested millions of searching keywords in nearly 20 languages on Google search engine and in fact the page views from search engine have been the main source of the advertisement flow. The alliance website marketing means that Lightinthebox.com provides standard copies and product contents to alliance websites and after customers visiting Lightinthebox .com website through alliance website and making deals, Lightinthebox.com returns certain proportion of selling profit to the alliance websites. What is worth mentioning is the social advertising marketing of Lightinthebox.com. Lightinthebox.com employed large numbers of people to post on social networking sites such as Facebook. The facts have proved the remarkable effectiveness of this advertising way and $3 \%$ website traffic in the United States from the Facebook website. But the cost of social advertising marketing is higher. By2012, the advertising marketing costs of Lightinthebox.com raised added million yuan and the main cost from overseas staff wages.

The Lightinthebox.com self-run cross-border E-commerce model eliminates the intermediate links and holds profits firmly in hand. But due to remove a large amount of the intermediate links, there are greatly increases of quality control risks, external marketing costs, logistics costs, inventory costs and so on. So the success key of this business model is how to avoid risks and reduce costs.

\section{B. Alibaba.com-transformation from information platform to integrated service provider}

The information platform model of cross-border Ecommerce is gradually transforming to integrated service providers and at the same time extending upstream and downstream industry chain to control profit.

Alibaba.com as the typical case of transformation from platform model to integrated service provider is not just confined to a trading information interaction platform. It wants to build the foreign trade ecosystem and provides one-stop services integrating trading, logistics and payments. Alibaba.com can establish a set of trade credit system through the big data accumulation and analysis to improve the whole foreign trade links, reduce risks and increase customer dependence and trust on it.

Since 2010 Alibaba.com has made its subordinate onetouch.alibaba.com becoming a comprehensive service provider for small and medium-sized enterprises. Alibaba.com attracts small exporters and enterprises without import and export rights by freely providing basic services and grants foreign trade service subsidies to foreign trade enterprises. The foreign trade enterprises joining Alibaba.com integrated platform can not only save cost and get extra subsidies but also save other expenses incurring in specific business such as shipping, the foreign exchange verification, commodity inspection, etc. Alibaba.com can get a lot of real transaction data about orders, logistics, tax rebates and so on to construct the foreign trade enterprise credit vouchers which can provide convenience for lately trade and financing loans. The trading data of every foreign trade enterprises' transaction including trading volume, trading object, logistics information, customs clearance data and so on can be accumulated to generate foreign trade credit system which will greatly reduce the trust cost between buyers and sellers and let them better judge each other's strength and credibility to reach the transaction.

\section{Summary of case analysis}

Alibaba.com's integrated solutions of the foreign trade services make the cross-border E-commerce platform into an one-stop integrated service platform with more service functions than the information platform. Alibaba.com uses service stickiness to enhance differentiation of platform.

Lightinthebox.com is some set of product categories' exclusive sales platform. It has good product differentiation and specialization and at the same time further integrates upstream and downstream to realize profits maximization and service standardization.

This is the two main different development roads of China cross-border E-commerce namely comprehensiveness and professionalization and the key factors involving which road to choose for cross-border E-commerce enterprises are their resources and abilities.

\section{CONCLUSION}

This paper analyzes the development stages and situations of China cross-border E-commerce. According the value chain analysis method and with specific cases, this paper gives three kinds of China cross-border E-commerce the business models that are the self-run E-commerce model, the information platform model and the integrated service provider model. The main conclusions are as follows:

First, the self-run model of cross-border E-commerce is the highly profitable model. By the analysis of Lightinthebox.com, the self-run cross-border E-commerce integrates the upstream suppliers and downstream service providers and puts the core competitiveness on the cross-border network marketing to gain much higher profits than traditional foreign trade.

Second, the information platform model of cross-border Ecommerce remains rapidly developing. As the earliest crossborder E-commerce model it occupies the development opportunities and half of the cross-border E-commerce share.

Third, the integrated service provider model is the development trend of cross-border E-commerce and will greatly attract the foreign trade sellers through establishing perfect payment, logistics, order management, quality inspection and other service systems.

\section{References}

[1] Zhangbin,Liuxiaojun,Taozhang. "The Study of Current Situation and Operation Pattern of the Cross-border E-commerce Logistics in China" . China Business and Market, vol.1, pp.55-56, January 2015.

[2] Nuray Terzia. "The Impact of E-commerce on International Trade and Employment". Procedia Social and Behaviora Sciences, vol.24, pp. 745753, 2011.

[3] AliResearch. "The China cross-border E-commerce development report 2016".G20 series study,September 2016.

[4] iResearch. "2016 China import cross-border retail electronic commerce industry research report", March 2016.

[5] Global Science and technology. "China's cross-border electricity trading scale will reach 12 trillion". http://tech.huanqiu.com/internet/201609/9392455.html, September 2016.

[6] Michael Rappa. "The Utility Business Model and Future of Computing Services" .IBM Systems Journal, vol.1,No.43, pp.32-42,2004.

[7] Weill,P. \& Vitale,M. R. "Place to Space: Migrating to E-business Models".Harvard Business Press, 2001.

[8] Paul Timmers. "Business models for electronic markets". Electronic Markets Joural, vol.2, pp.3-8,August,1998.

[9] The China electronic commerce research center. "2015-2016 China's exports cross-border E-commerce development report" . China council for the promotion of international trade, August 17,2016.

[10] WIKI. Lightinthebox[N]. http://www.baike.com/wiki

[11] Wang huan. "Cross border trade with China's market economic system" East China University Of Science and Technology, September 2015. 